\title{
Hubungan Kondisi Lingkungan Dan Perilaku Masyarakat Dengan Kejadian Filariasis Di Desa Muaro Putuih Wilayah Kerja Puskesmas Tiku Kabupaten Agam
}

\author{
Weni Sartiwi ${ }^{a}$

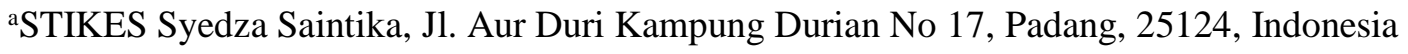 \\ e-mail korespondensi : wenisartiwi.85weni@gmail.com
}

\begin{abstract}
Filariasis is a systemic infection caused by filarial worms that live in the human lymph nodes and blood. The most important thing to do is to decrease the filariasis incidence that influenced by environmental condition and behavior. The purpose of this research was to know relationship between environmental condition and people behavior with filariasis incidence at muaro putuih village tiku public health centre working area agam district. Type of this research was descriptive analitik research with cross sectional design. The population of this research was all head of family at muaro putuih village tiku public health centre working area agam number 100 head of family with 50 head of family samples. Taking samples in this research was using simple random sampling. This research was done on February 10 until March 2, 2016. The data was collected using a questionnaire. Data processing techniques were editing, coding, entry and cleaning. Univariate analysis was analyzed using chi-square test shown in cross table form. The results showed that from 50 respondents, more than half of respondents (54\%) had environmental at risk, more than half of respondents (54\%) had bad behavior, more than half of respondents (58\%) not suffering from filariasis. There was relationship between environmental condition and filariasis incidence $(p=0.000)$, there was relationship between behavior and filariasis incidence $(p=1.000)$, there was a relationship between medication adherence and recovery $(p=0.017)$ at muaro putuih village tiku public health centre working area agam district. It is expected for public health centre in order to give health education about the filariasis disease.
\end{abstract}

Keywords: Environmental condition, Behavior, Filariasis incidence

\begin{abstract}
Abstrak
Filariasis merupakan adalah suatu infeksi sistemik yang disebabkan oleh cacing filarial yang hidup dalam kelenjar limfe dan darah manusia. Hal terpenting yang harus dilakukan adalah menurunkan angka kejadian filariasis yang dipengaruhi oleh kondisi lingkungan dan perilaku. Tujuan penelitian ini untuk mengetahui hubungan kondisi lingkungan dan perilaku masyarakat dengan kejadian filariasis di Desa Muaro Putuih Wilayah Kerja Puskesmas Tiku Kabupaten Agam. Jenis penelitian ini adalah analitik dengan desain penelitian cross sectional. Populasi adalah seluruh KK yang ada di Desa Muaro Putuih Wilayah Kerja Puskesmas Tiku Kabupaten Agam yang berjumlah 100 KK dengan sampel 50 KK. Pengambilan sampel menggunakan simple random sampling. Penelitian ini dilakukan pada tanggal 10 Februari s/d 2 Maret 2016. Pengumpulan data dengan kuesioner. Teknik pengolahan data yaitu editing, coding, entry, dan cleaning. Analisa univariat dan bivariat dianalisis menggunakan uji chi-square. Hasil penelitian bahwa lebih dari separuh responden (54\%) kondisi lingkungan beresiko, lebih dari separuh responden (54\%) perilaku tidak baik, lebih dari separuh responden $(58 \%)$ tidak menderita filariasis. Terdapat hubungan antara kondisi lingkungan dan kejadian filariasis $(\mathrm{p}=0,000)$, terdapat hubungan antara perilaku dan kejadian filariasis $(\mathrm{p}=0,017)$. Diharapkan agar dapat memberikan pendidikan kesehatan tentang penyakit filariasis.
\end{abstract}

Kata kunci: Kondisi lingkungan, Perilaku, Kejadian filariasis

\section{PENDAHULUAN}

Filariasis adalah suatu infeksi sistemik yang disebabkan oleh cacing filarial yang cacing dewasanya hidup dalam kelenjar limfe dan darah manusia, dan secara biologik ditularkan oleh serangga (nyamuk), penyakit ini bersifat menahun atau kronis dan apabila tidak mendapatkan pengobatan, maka akan menimbulkan cacat menetap berupa pembesaran kaki, pembesaran lengan, payudara, dan alat kelamin wanita maupun laki-laki. Penyakit ini di sebabkan oleh 3 species cacing filaria yaitu : wuchereria bancrofti, brugia malayi, dan brugia timori (Akhsin zulkoni, 2011).

Filariasis juga di kenal dengan sebutan elephantiasis atau dalam bahasa 
Indonesia di kenal sebagai penyakit kaki gajah dan di beberapa daerah menyebutnya untut, adalah penyakit menular kronis yang di sebabkan karena infeksi cacing filaria, dimana cacing ini menyerang saluran dan kelenjar getah bening sehingga menyebabkan rusaknya sistem limfe dan dapat mengakibatkan cacat seumur hidup serta stigma sosial bagi penderita dan keluarganya. Secara tidak langsung, penyakit yang ditularkan berbagai jenis nyamuk dapat berdampak pada penurunan produktifitas kerja penderita, beban keluarga dan menimbulkan kerugian ekonomi bagi negara. (Depkes RI, 2005).

Penyakit filariasis, walaupun tidak tersebar di seluruh dunia, sangat utama terdistribusi merata di daerah tropis bersamaan dengan adanya jenis vektor penyakit. Diperkirakan 300 juta orang, terutama di India, Asia tenggara, dan Subhara Afrika, hidup di daerah endemik filariasis limfatik, dengan kira-kira 130 juta orang yang terinfeksi filariasis (G Thomas strickland, 2007).

Berdasarkan laporan sampai tahun 2009 dari kabupaten/kota, kasus kronis filariasis yang dilaporkan sebanyak 11,945 kasus, filariasis dapat ditularkan oleh seluruh jenis spesies nyamuk. Di Indonesia diperkirakan terdapat lebih dari 23 spesies vektor nyamuk penular filariasis yang terdiri dari genus anopheles, aedes, culex, mansonia, dan armigeres (Kemenkes RI, 2010).

Di Indonesia diperkirakan filariasis telah tersebar luas hampir di semua propinsi, pada tahun 2012 berdasarkan laporan dari daerah dan hasil survey pada kabupaten/kota adalah 302 kabupaten/kota dari 497 kabupaten/kota di Indonesia atau sebesar 60,7\% sedangkan 195 kabupaten/kota $(39,3 \%)$ tidak endemis filariasis dan indonesia termasuk negara terbesar ke dua yang penduduknya tertular filariasis setelah india (Depkes RI, 2013).

Pada tahun 2015 di Sumatera Barat terdapat 238 orang penderita filariasis yang tersebar di 11 Kabupaten yaitu Pasaman (1), Agam (48), Lima Puluh Kota (14),
Padang Pariaman (27), Pesisir Selatan (38), Tanah Datar (1), Sijunjung (1), Padang (35), Bukit Tinggi (11) Pasaman Barat (49), Damas Raya (3). (Dinas Kesehatan Propinsi 2015). Kasus filariasis terbesar di Sumbar yaitu dari Kabupaten Agam. Berdasarkan hasil dari survey darah jari (SDJ) yang dilakukan oleh Dinas Kesehatan, pada tahun 2015 ditemukan kasus filariasis sebanyak 48 orang dari 16 Kecamatan dan 22 Puskesmas, di antaranya adalah Padang Tarok (0), Baso (0), Biaro (0), Lasi (0), Magek (0), Pakan Kamis (2), Kapau (0), Palupuh (1), Sei. Puar (0), Pd. Luar (0), IV Koto (0), Malalak (0), Matur (0), Koto Alam (1), Maninjau (1), Palembayan (0), Pasar Ahad (1) Lubuk Basung (4), Manggopoh (12), Tiku (21), Batu Kambing (0), Bawan (5) (Dinkes Agam 2015). Hasil data yang di dapatkan di Dinas Kesehatan Kabupaten Agam tersebut maka Wilayah Tiku merupakan daerah terbanyak penderita filariasis yaitu 21 orang yang menderita filariasis dari $100 \mathrm{KK}$.

Sebagai bagian dari Program Pasifik untuk Menghilangkan Filariasis Limfatik (PacELF), survei awal dilakukan pada 1999 dan 2004 di Nauru untuk menentukan prevalensi filariasis melalui tes immunochromatotraphic cepat (TIK). Pada tahun 1999, survei menunjukkan prevalensi filariasis sebesar $0,26 \%$, dan Nauru diklasifikasikan sebagai negara nonendemik pada saat itu. Pada tahun 2004, prevalensi yang dihasilkan dari survei adalah 1,66\%. Karena melebihi 1,0\%, prevalensi tinggi ini menjamin penerapan Administrasi Obat Massal (MDA) sesuai dengan pedoman WHO dan memunculkan kebutuhan mendesak untuk memulihkan kembali kebijakan filariasis di Nauru, sebagai tahun target untuk eliminasi filariasis di Pasifik. tahun 2010. Sebanyak 1.513 orang terdaftar untuk survei pada bulan Januari 2007. Filariasis positif terdeteksi $(0,2 \%)$ oleh tes ICT. Nauru dipastikan sebagai negara non-endemis dan oleh karena itu tidak memerlukan implementasi MDA. Prevalensi tidak 
bervariasi secara signifikan sesuai dengan karakteristik demografi. Dua dari tiga kasus positif filariasis tinggal di distrik yang sama dan yang lainnya tinggal di distrik tetangga (Emi Sasagawa,2009).

Berdasarkan penelitian sebelumnya oleh Betlinizar pada tahun 2006 di dapatkan hasil bahwa terdapat dua faktor yang berhubungan dengan kejadian filariasis yaitu faktor lingkungan dan faktor prilaku, faktor lingkungan dan prilaku perlu di teliti lebih lanjut karena dari kedua faktor tersebut merupakan faktor yang beresiko dengan kejadian filariasis.

Wilayah Tiku merupakan daerah endemis filariasis, yang umumnya adalah daerah dataran rendah, terutama di perdesaan, pantai, persawahan, rawa-rawa dan hutan. Beberapa faktor yang dapat memicu timbulnya kejadian filariasis diantaranya adalah faktor lingkungan dan prilaku masyarakat faktor lingkungan merupakan salah satu yang mempengaruhi kepadatan vektor filariasis. Lingkungan ideal dapat dijadikan tempat potensial untuk perkembang biakan dan tempat istirahat nyamuk sehingga kepadatan nyamuk akan meningkat (Depkes RI 2009).

Lingkungan yang terdiri dari lingkungan fisik, biologik, dan sosial budaya secara langsung maupun tidak langsung dapat mempengaruhi kejadian filariasis. Lingkungan fisik misalnya, genangan air, semak-semak, dan lain sebagainya, sangat berkaitan dengan kehidupan vektor, tempat istirahat vektor, dan tempat perindukan vektor. Faktor prilaku masyarakat seperti menggunakan kelambu saat tidur, pemasangan kawat kasa pada ventilasi dan lain-lain juga dapat menjadi praktek pencegahan penularan filariasis, agar vektor filariasis yang berupa nyamuk tidak mudah menggigit manusia yang berada di dalam atau diluar rumah (Depkes RI, 2006).

Kebiasaan keluar rumah pada malam hari merupakan budaya masyarakat yang sangat sulit untuk di tinggalkan. Kebiasaan ini merupakan suatu nilai-nilai kemasyarakatan yang tidak tertulis namun sangat di lestarikan oleh. Ukuran tingkat sosialisasi masyarakat di sini di ukur dengan ada atau tidaknya mereka keluar rumah pada malam hari baik hanya sekedar duduk di kedai kopi atau kerumah tetangga untuk sekedar ngobrol saja. Bila prilaku ini tidak di ikuti maka yang bersangkutan akan di sisihkan dalam pergaulan hari-hari atau dengan kata lain di kucilkan.

Berdasarkan survey pendahuluan yang dilakukan peneliti pada tanggal 03 September 2015 menunjukan bahwa kondisi lingkungan di Desa Muaro Putuih Wilayah Tiku masih kurang baik. Dari sebanyak $10 \mathrm{KK}$ dimana $6 \mathrm{KK}$ terkena filariasis dan $4 \mathrm{KK}$ tidak filariasis di dapatkan hasil bahwa rumah warga terdapat semak-semak, terdapat genangan air, dan sebagian dengan kondisi terbuka, menggenang dan kotor, sehingga di dapatkan keberadaan jentik nyamuk, banyak ventilasi rumah warga di pasang kawat kasa, dan masyarakat menggunakan kelambu saat tidur, mempunyai kebiasaan menggantung pakaian, sering keluar rumah tidak memakai baju atau celana panjang terutama malam hari. Dari latar belakang di atas, maka peneliti telah melakukan penelitian tentang hubungan kondisi lingkungan dan prilaku masyarakat dengan kejadian filariasis di Desa Muaro Putuih Wilayah Kerja Puskesmas Tiku Kabupaten Agam tahun 2016.

\section{METODE}

Jenis penelitian yang penelitian ini adalah Analitik yaitu penelitian yang dilakukan terhadap dengan pendekatan cross sectional. Penelitian dilaksanakan mulai Januari s/d Maret 2016 di Desa Muaro Putuih Wilayah Kerja Puskesmas Tiku Kabupaten Agam. Populasi adalah seluruh KK baik penderita filariasis dan yang bukan penderita filariasis berjumlah 100 KK sehingga sampel didapatkan adalah $50 \mathrm{KK}$ dengan metode pengambilan sampel yaitu simple random sampling. Etika penelitian meliputi Informed consent (lembaran persetujuan), Anonimity (tanpa 
nama), Confidentiality (kerahasiaan), Beneficence, Justice, Autonomy, Nonmaleficence. Instrumen yang digunakan adalah kuesioner dan lembar observasi. Prosedur pengumpulan data dengan Editing (penyusunan dan pemeriksaan data), Coding (pengkodean data), Entry Data (memasukan data), Cleaning (membersihkan data), Tabulating. Uji statistik yang digunakan adalah uji Chi-Square pada tingkat kepercayaan $95 \%$ dengan menggunakan program komputer (software)

HASIL

Tabel 1. Distribusi Frekuensi Responden Berdasarkan Kondisi Lingkungan

\begin{tabular}{clll}
\hline NO & Variabel & f & $\%$ \\
\hline 1 & Kondisi Lingkungan & & \\
& $-\quad$ Beresiko & 27 & 54 \\
& $-\quad$ Tidak beresiko & 23 & 46 \\
\hline 2 & Perilaku & & \\
& $-\quad$ Baik & 27 & 54 \\
& $-\quad$ Tidak baik & 23 & 46 \\
\hline 3 & Kejadian Filariasis & 21 & 42 \\
& $-\quad$ Filarisis & 29 & 58 \\
\hline
\end{tabular}

Tabel 2. Hubungan Kondisi Lingkungan Dan Perilaku Masyarakat Dengan Kejadian Filariasis

\begin{tabular}{|c|c|c|c|c|c|c|c|c|c|}
\hline \multirow[t]{3}{*}{ No } & \multirow[t]{3}{*}{ Variabel } & \multirow[t]{3}{*}{ Klasifikasi } & \multicolumn{4}{|c|}{ Kejadian Filariasis } & \multicolumn{2}{|c|}{ Total } & \multirow[t]{3}{*}{ p.value } \\
\hline & & & \multicolumn{2}{|c|}{ Filariasis } & \multicolumn{2}{|c|}{$\begin{array}{c}\text { Tidak } \\
\text { Filariasis } \\
\end{array}$} & \multirow[b]{2}{*}{ f } & \multirow[b]{2}{*}{$\%$} & \\
\hline & & & f & $\%$ & $\mathbf{f}$ & $\%$ & & & \\
\hline \multirow[t]{3}{*}{1.} & Kondisi & - Beresiko & 20 & 74,1 & 7 & 25,9 & 27 & 100 & 0,000 \\
\hline & lingkungan & - Tidak beresiko & 1 & 4,3 & 22 & 95,7 & 23 & 100 & \\
\hline & Jumlah & & 21 & 42 & 29 & 58 & 50 & 100 & \\
\hline \multirow[t]{3}{*}{2} & Prilaku & - Tidak baik & 16 & 59,3 & 11 & 40,7 & 27 & 16 & 0,017 \\
\hline & masyarakat & - Baik & 5 & 21,7 & 18 & 78,3 & 23 & 5 & \\
\hline & & Jumlah & 21 & 42 & 29 & 58 & 50 & 21 & \\
\hline
\end{tabular}

Tabel 1 dapat dilihat bahwa lebih dari separuh responden (54\%) memiliki kondisi lingkungan yang beresiko, lebih dari separuh responden (54\%) memiliki perilaku tidak baik terhadap kejadian filariasis dan lebih dari separuh responden $(58 \%)$ tidak beresiko menderita penyakit filariasis.

Tabel 2 menunjukkan, berdasarkan hasil uji statistik terdapat hubungan antara kondisi lingkungan dan prilaku dengan kejadian filariasis didesa muaro putuih Wilayah Kerja Puskesmas Tiku Kabupaten Agam

Weni Sartiwi., Hubungan Kondisi Lingkungan dan....

\section{PEMBAHASAN}

Lebih dari separuh responden (54\%) memiliki kondisi lingkungan yang beresiko terhadap kejadian filariasis di Desa Muaro Putuih Wilayah Kerja Puskesmas Tiku Kabupaten Agam. Berdasarkan hasil dari observasi terhadap kondisi lingkungan responden didapatkan sebagian besar (66\%) kondisi lingkungan responden terdapat rawa $<10 \mathrm{~m}$ dan pertanyaan yang diajukan pada responden sebagian besar (62\%) responden memelihara ternak besar seperti sapi atau kambing. Banyaknya responden yang memiliki kondisi lingkungan yang beresiko menyebabkan banyaknya warga yang menderita penyakit filariasis. Penelitian yang dilakukan 
Ningsih (2011) mengenai gambaran pengetahuan dan kondisi lingkungan pasien filariasis menunjukkan bahwa sebagian besar responden $67 \%$ kurang mengetahui tentang filariasis sehingga banyak responden yang memiliki kondisi lingkungan beresiko terhadap filariasis. Lingkungan merupakan seluruh kondisi yang ada disekitar manusia dan pengaruhnya dapat mempengaruhi perkembangan dan perilaku orang atau kelompok. Apabila lingkungan seseorang baik maka akan mempengaruhi seseorang untuk berperilaku hidup sehat (Nursalam, 2010). Menurut analisa peneliti, responden memiliki kondisi lingkungan beresiko dikarenakan masih kurangnya informasi yang didapatkan oleh responden tentang penyakit filariasis dari pihak kesehatan, televisi, dan media cetak seperti koran dan artikel kesehatan. Salah satunya terlihat bahwa tidak adanya program penyuluhan tentang penyakit filariasis yang dilakukan oleh tenaga kesehatan di lingkungan tempat tinggal responden. Kondisi lingkungan tidak beresiko dapat disebabkan sudah ada informasi yang didapat oleh responden dari pihak kesehatan, televisi, dan artikel kesehatan. Salah satunya dapat terlihat dari tidak adanya sampah di sekitar rumah responden.

Perilaku tidak baik terhadap kejadian filariasis di Desa Muaro Putuih Wilayah Kerja Puskesmas Tiku Mutiara Kabupaten Agam. Berdasarkan hasil dari pertanyaan perilaku yang diajukan pada responden, sebanyak 17 responden (34\%) menyatakan jarang memakai kelambu pada malam hari. Perilaku kurang baik dari responden dapat disebabkan kurangnya informasi yang didapatkan oleh responden tentang pencegahan penyakit filariasis. Penelitian yang dilakukan Lailatul M. dan Eram T. (2015) mengenai hubungan perilaku dengan kejadian filariasis menunjukkan bahwa warga masyarakat masih memiliki kebiasaan keluar malam hari untuk kegiatan seperti bekerja, kegiatan yasinan, shalat dimesjid, pergi ke warung.
Kebiasaan berada di luar rumah sampai larut malam akan memudahkan gigitan nyamuk, dimana vektor nyamuk Culex penyebab filariasis di Kota Pekalongan memiliki kebiasaan menggigit pada malam hari (nocturnal) beberapa jam setelah matahari terbenam sampai sebelum matahari terbit dan bersifat eksofilik dan endofilik. Perilaku adalah tindakan atau aktivitas dari manusia yang dapat diamati secara langsung maupun yang tidak dapat diamati oleh pihak luar. Apabila seseorang memiliki perilaku yang baik maka seseorang dapat memiliki pola hidup sehat (Notoatmodjo, 2011). Menurut analisa peneliti, responden yang memiliki perilaku kurang baik dapat disebabkan karena masih kurangnya informasi responden tentang penyakit filariasis dan tidak adanya pengalaman dalam upaya pencegahan penularan penyakit filariasis. Salah satunya dapat dilihat dari adanya kaleng bekas yang dapat menampung air hujan di lingkungan tempat tinggal responden dan masih adanya baju yang bergantungan di kamar. Responden yang memiliki perilaku baik dapat disebabkan karena sudah adanya informasi yang di dapat oleh responden dari pihak kesehatan, televisi, dan media cetak lainnya sehingga responden dapat memiliki perilaku baik untuk menghindari penyakit filariasis seperti tidak adanya baju yang di gantung di kamar responden sehingga nyamuk tidak bisa berkembangbiak.

Lebih dari separuh responden (58\%) tidak menderita penyakit filariasis di Desa Muaro Putuih Wilayah Kerja Puskesmas Tiku Kecamatan Kabupaten Agam. Berdasarkan hasil dari observasi tentang kejadian filariasis, terdapatnya responden yang menderita filariasis disebabkan karena kondisi lingkungan yang beresiko dan perilaku yang kurang baik terhadap kejadian filariasis. Hal ini dapat dilihat dari banyaknya responden yang memiliki hewan ternak, terdapatnya rawa-rawa disekitar pemukiman warga, dan banyaknya sampah yang dapat menampung genangan air. Penelitian yang 
dilakukan oleh Puji J, Maya K, I Made J, dan Dewi S (2009) menyatakan responden yang memiliki kebiasaan keluar rumah pada malam hari memiliki peluang 5,4 kali lebih besar untuk menderita penyakit filariasis dibandingkan dengan responden yang tidak memiliki kebiaasan seperti itu. Kurangnya informasi yang didapat mengenai penyakit filariasis. Filariasis adalah penyakit yang disebabkan oleh infeksi parasit nematode yang dapat menurunkan produktivitas penderitanya karena mengalami gangguan fisik (Widoyono, 2005). Menurut analisa peneliti, responden yang menderita penyakit filariasis disebabkan oleh kondisi lingkungan yang beresiko dan perilaku kurang baik terhadap kejadian filariasis. Hasil observasi peneliti, didapatkan sebagian besar responden memiliki kondisi lingkungan yang beresiko terhadap kejadian filariasis seperti terdapatnya rawa-rawa di sekitar pemukiman warga, dan adanya warga yang memelihara hewan ternak di samping rumah. Responden yang tidak menderita filariasis terlihat dari tidak adanya rawa-rawa di sekitar pemukiman warga dan tidak adanya warga yang memelihara hewan ternak di samping rumah.

Berdasarkan analisis hubungan dengan menggunakan uji statistik ChiSquare antara kondisi lingkungan dengan kejadian filariasis didapatkan nilai $\mathrm{p}=0,000$ dengan demikian dapat disimpulkan bahwa terdapat hubungan yang bermakna $\left(\mathrm{H}_{\mathrm{a}}\right.$ diterima) antara kondisi lingkungan dengan kejadian filariasis di Desa Muaro Putuih Wilayah Kerja Puskesmas Tiku Kecamatan Kabupaten Agam. Penelitian yang dilakukan Haryadi (2009) mengenai faktor yang mempengaruhi kejadian filariasis didapatkan $66,7 \%$ responden memiliki kondisi lingkungan yang beresiko untuk terjadinya filariasis. Hal ini disebabkan karena kurangnya informasi yang didapat oleh responden tentang penyakit filariasis sehingga tidak adanya upaya masyarakat dalam upaya pencegahan penyakit filariasis.
Lingkungan merupakan seluruh kondisi yang ada disekitar manusia dan pengaruhnya dapat mempengaruhi perkembangan dan perilaku orang atau kelompok. Apabila lingkungan seseorang baik maka akan mempengaruhi seseorang untuk berperilaku hidup sehat (Nursalam, 2010). Menurut analisa peneliti, kondisi lingkungan sangat mempengaruhi terhadap kejadian filariasis karena penyebaran penyakit filariasis ditularkan melalui gigitan nyamuk. Apabila lingkungan tidak bersih maka nyamuk akan berkembangbiak sangat cepat sehingga sangat mudah menularkan penyakit filariasis kepada orang sehat. Jadi, disini terdapat kesesuaian antara pendapat ahli dengan hasil penelitian yang menunjukkan bahwa kondisi lingkungan sangat mempengaruhi terhadap kejadian filariasis. Berdasarkan analisis hubungan dengan menggunakan uji statistik Chi-Square antara perilaku dengan kejadian filariasis didapatkan $\mathrm{p}=0,017$ dengan demikian dapat disimpulkan bahwa terdapat hubungan yang bermakna $\left(\mathrm{H}_{\mathrm{a}}\right.$ diterima $)$ antara perilaku dengan kejadian filariasis di Desa Muaro Putuih Wilayah Kerja Puskesmas Tiku Kecamatan

Kabupaten Agam Tahun 2016. Penelitian yang dilakukan Mahmud (2010) mengenai hubungan perilaku dengan kejadian filariasis menunjukkan bahwa sebagian besar responden $(56,6 \%)$ memiliki perilaku kurang baik sehingga mengakibatkan tidak adanya kepedulian dari reponden untuk mencegah terjadinya penyakit filariasis. Perilaku adalah tindakan atau aktivitas dari manusia yang dapat diamati secara langsung maupun yang tidak dapat diamati oleh pihak luar. Apabila seseorang memiliki perilaku yang baik maka seseorang dapat memiliki pola hidup sehat (Notoatmodjo, 2011). Menurut analisa peneliti, perilaku sangat mempengaruhi terhadap kejadian filariasis karena seseorang yang berperilaku tidak baik dapat memiliki kondisi lingkungan yang tidak bersih. Apabila lingkungan tidak bersih maka dapat menimbulkan 
berbagai penyakit. Jadi, disini terdapat kesesuaian antara pendapat ahli dengan hasil penelitian yang menunjukkan bahwa perilaku sangat mempengaruhi terhadap kejadian filariasis.

\section{KESIMPULAN DAN SARAN}

\section{Kesimpulan}

Berdasarkan hasil penelitian dan pembahasan tentang hubungan kondisi lingkungan dan perilaku masyarakat dengan kejadian filariasis, maka didapatkan kesimpulan bahwa ada hubungan kondisi lingkungan dengan kejadian filariasis $(p=0,000)$ dan ada hubungan perilaku dengan kejadian filariasis $(\mathrm{p}=0,017)$ di Desa Muaro Putuih Wilayah Kerja Puskesmas Tiku Kecamatan Kabupaten Agam.

\section{Saran}

Diharapkan petugas kesehatan dapat melakukan pemeriksaan dini secara rutin dan berlanjut kepada seluruh masyarakat terkait kasus filariasis baik yang sudah terjadi filariasis mapun yang belum atau masih beresiko terjadi filariasis.

\section{DAFTAR PUSTAKA}

Betlinizar. 2006. Faktor Resiko Kejadian Filariasis di Wilayah Tiku Kecamatan Tanjung Mutiara Kab. Agam. Diakses dari http://agam.ac.id pada tanggal 23 September 2015.

Departemen Kesehatan RI. 2015. Epidemiologi Filariasis. Diakses dari http:// Bitjen P2 \& PL pada tanggal 26 Oktober 2015.

Depkes RI. 2015. Data Statistik Penyakit Menular. Diakses dari http://depkesri.ac.id pada tanggal 14 Oktober 2015.

Dinas Kesehatan Propinsi Sumbar. 2015. Laporan P2P. Diakses dari http://laporan p2p.ac.id pada tanggal 1 Desember 2015.
Dinas Kesehatan Propinsi Sumbar. 2014. Laporan Tahunan Penyakit Menular. Diakses dari http://dinkessumbar.ac.id pada tanggal 24 Oktober 2015.

Dinas Kesehatan Kabupaten Agam. 2015. Data Penyakit Menular Kabupaten Agam. Diakses dari http://dinkesagam.ac.id pada tanggal 13 Desember 2015.

Emi, S. (2009). Prevalence of Lymphatic Filariasis from 1999 through 2007 in Nauru, a Set of Solitary Island in the Southern Pacific. Tropical Medicine and Health vol. 37,Iss.2, 63. DOI:10.2149/tmh.2009-02

Haryadi. 2009. Faktor Yang Mempengaruhi Kejadian Filariasis Di Puskesmas Jatiluhur. Diakses dari http://pustakaunpad.ac.id pada tanggal 17 Maret 2016.

Juriatusti, P,Kartika, M, Djaja, made, Susanna, D. (2009). Faktor resiko kejadian filariasis di kelurahan Jati Sampurna. Makara Kesehatan. Vol 14,No 1,Juni 2010: 31 - 36 .

Laporan Tahunan P2 Filariasis. 2015. Puskesmas Tiku.

Mahmud. 2010. Hubungan Perilaku Dengan Kejadian Filariasis Di Puskesmas Kediri. Diakses dari http://pustakaugm.ac.id pada tanggal 13 Maret 2016.

Munawwarah. L, Tunggul E,P. Evaluasi Program Eliminasi Filariasis dari aspek prilaku dan perubahan lingkungan. Unnes Journal of Public Health 5 (3), Juli 2016 : 195 - 204. 
NERS: Jurnal Keperawatan, Volume 14, No. 1, Maret 2018, (Hal. 11-18)

Ningsih, Kurnia. 2011. Gambaran Pengetahuan Dan Kondisi Lingkungan Pasien Filariasis di Puskesmas Jatinegara. Diakses dari http://komunitaskep.ac.id pada tanggal 15 Maret 2016.

Notoatmodjo. 2011. Konsep Prilaku Kesehatan. Jakarta: Rineka Cipta.

Notoatmodjo. 2010. Metodologi Penelitian. Jakarta: Rineka Cipta.

Retna. 2010. Hubungan Perilaku Dengan Kejadian Filariasis Di Desa Sukoharjo. Diakses dari http://komunitas.ac.id pada tanggal 18 Maret 2016.

Strickland, G. Thomas. 2007. Huntyer's Tropical Medicine and Emerging Infectious Discase. W.B. Sounder Company, Pennsylvania.

Widoyono. 2005. Penyakit Tropis. Erlangga: Semarang.

Zulkomi, Akhsin. 2011. Parasitologi. Yogyakarta: Nuha Medika. 